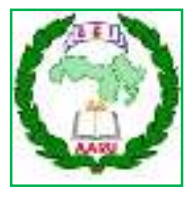

Arab Univ. J. Agric. Sci., Ain Shams Univ., Cairo, Egypt

28(3), 829-843, 2020

Website: http://ajs.journals.ekb.eg

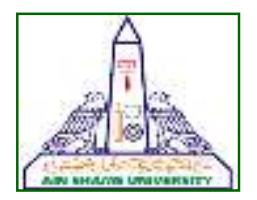

829

\title{
PRODUCTIVE AND IMMUNOLOGICAL RESPONSES OF BROILER CHICKS TO SUPPLEMENTATION OF DIFFERENT COPPER FORMS
}

\author{
El-Wardany I. ${ }^{1}$, Abdel-Hamid A.E. ${ }^{2}$, Ayman M. Morsi ${ }^{2}$ \\ and Asmaa Sh. El-Naggar ${ }^{*}$
}

1- Poultry Production Dept., Fac. of Agric., Ain Shams Univ., P.O. Box 68, Hadayek Shoubra 11241, Cairo, Egypt

2- Animal and Poultry Production Dept., Fac. of Agric., Damanhour Univ., Egypt

*Corresponding author: asmaa.elnaggar@agr.dmu.edu.eg

Received 30 May, 2020

Accepted 17 August, 2020

\section{ABSTRACT}

Two hundred and ten unsexed broiler chicks (Arbor Acres) at 7 day of age were used to study the effect of dietary supplementation of different Copper (Cu) forms i.e. inorganic (copper sulfate, $\mathrm{CuSO}_{4}$ ), organic (copper methionine $\mathrm{Cu}_{2}$-Met) or nano inorganic copper particles (Cu-NP) on the productive performance, hematological and biochemical constituents of blood and immune response of broiler chicks. They were randomly divided into seven dietary treatments with five replicate cages per treatment, six chicks for each. The first group was fed the basal diet without any supplementation (control); while the $2^{\text {nd }}$ and $3^{\text {rd }}$ groups were fed the same diet supplemented with 50 and 100 ppm of inorganic $\mathrm{Cu}$ (copper sulfate, $\mathrm{CuSO}_{4}$ ), respectively. The $4^{\text {th }}$ and $5^{\text {th }}$ groups were fed the basal diet supplemented with 50 and 100 ppm of organic $\mathrm{Cu}$ (copper methionine $\left.\mathrm{Cu}_{2}-\mathrm{Met}\right)$, respectively. The $6^{\text {th }}$ and $7^{\text {th }}$ groups were fed the basal diet supplemented with 50 and $100 \mathrm{ppb}$ of nano inorganic copper (Cu-NP), respectively. Results showed that chicks fed the basal diet supplemented with different forms of $\mathrm{Cu}$ had significantly better LBW, BWG, FCR, economic efficiency and production index. Both organic and nano Cu-fed groups showed significantly better productive performance traits compared with the inorganic $\mathrm{Cu}-$ fed groups. Supplementation of different $\mathrm{Cu}$ forms decreased serum levels of total lipids, triglycerides, cholesterol, low density lipoprotein (LDL), whereas RBCs count, hemoglobin, PCV, glucose, globulin, thyroid hormones (T3-T4), immunoglobulin (IgM, IgG), and antioxidant enzymes activity (TAC-
GPX-GSH-SOD) were significantly increased compared with the control treatment. Additionally, $\mathrm{Cu}$ supplementation increased lactobacillus sp. while decreased total bacterial count (Salmonella, E. coli and Proteus) compared with the control group. In conclusion, $\mathrm{Cu}$ supplementation improved the growth performance, immune response and physiological status of broiler chickens. Broilers fed organic and nano Cu-supplemented diets had better growth performance and immune response than those fed inorganic copper.

Keywords: Copper, Broilers, Performance, Blood parameters, Immune response.

\section{INTRODUCTION}

The beneficial effect of copper $(\mathrm{Cu})$ on the development and functioning aspects of birds is very well documented in the literature (Collins et al 2010; Hatoriand Lutsenko, 2016; Ognik et al 2016 and Jarosz et al 2018). This element has an effective impact in conditioning and modulating many important metabolic processes in the living body i.e. it participates in binding of iron to haem in haemoglobin, synthesis of red blood cells, responsible for the structure of connective tissue and ensuring proper collagen cross-linking (Collins et al 2010). In addition, as a co-factor of many enzymes, $\mathrm{Cu}$ determines the correct course of certain metabolic pathways via enhancing energy metabolism in the respiratory- mitochondrial chains, synthesis and degradation of neurotransmitters, or redox signaling in angiogenesis (Hatori and Lutsenko, 2016). 
Davis and Mertz (1987) studied the essentiality and bioavailability of different $\mathrm{Cu}$ sources along with its safe levels for use by the commercial feed industry in poultry and livestock diets. Since, Cu from various sources has often been included to diets at different levels as an antimicrobial agent. Copper is a component of various antioxidant enzymes (i.e. cytochrome oxidase, superoxide dismutase), metal enzymes involved in energy and ferric metabolism (Klasing, 1998). Since, it is an important trace element for many physiological and biochemical processes. In poultry, copper deficiency results in growth retardation, abnormal bone formation and remodeling, hypochromic anemia and therefore it is considered as an essential element that has been used worldwide as a growth promoter in poultry and pigs. Indeed, several reports (Aboul-Ela et al 2000; Skrivanova et al 2001) indicated that Cu supplementation to poultry diets could improve growth performance and immunity. Recently, the tremendous nanotechnology development and its applications are ever more varied and specific, with a high potential for improving poultry and animal production. In this concern, Mroczek-Sosnowska et al (2015) declared that either Nano $\mathrm{Cu}$ or copper sulfate (CuSO4) are effective for stimulating the development of blood vessels and enhancing muscle growth during late stage of embryogenesis by increasing myofibrils size (hypertrophy) over their number (hyperplasia). This effect was confirmed by Velleman (2007) who found that the number of muscle fibers is established mainly in the prenatal period. (Febré, et al 2016) have reported that different $\mathrm{Cu}$ forms could be used as promising alternatives to prevent harmful bacteria and to promote growth performance. They added that both $\mathrm{CuSO}_{4}$ and Cu nanoparticles (Cu-NP) were effective as antibacterial and/ or growth promoters. Moreover, $\mathrm{Cu}$ NP was found to exhibit a variety of effects on animal performance depending on the source, particle size, dose growth period and animal species.

Little information about the immune-physiological effects of different Cu forms, especially nanoparticles, in birds is available in the literature. Therefore, the main objective of this investigation was to evaluate the influence of different forms of cupper i.e., inorganic (copper sulfate, $\mathrm{CuSO}_{4}$ ), organic (copper methionine $\mathrm{Cu}_{2}$-Met) and nano copper on the productive performance, blood profile and immunity of broilers.

\section{MATERIALS AND METHODS}

The present experiment was carried out at the Animal and Poultry Research Centre (El-Bostan Farm) belonging to Faculty of Agriculture, Damanhour University, during the period from April to June 2019. The study aimed at elucidating the beneficial effect(s) of supplementing broiler chicks diet with copper different levels and forms i.e. inorganic (copper sulfate, $\mathrm{CuSO}_{4}$ ), organic (copper-methionine) or nano inorganic copper (Cu-NP) on productive performance, blood plasma constituents, complete blood cell count (CBC) and immune - related parameters and responses.

\section{Birds and experimental design}

Total of 210 one day old broiler chicks (Arbor Acres) of both sexes, purchased from a local hatchery were used in this study. Upon arrival all chicks were brooded at $33^{\circ} \mathrm{C}$ for the first seven days of age. From the second week of age, they were randomly distributed into seven treatment groups of 30 chicks, each of five replicates, six birds per replicate. The first group was fed the basal diet without any supplementation (control), while the $2^{\text {nd }}$ and $3^{\text {rd }}$ groups were fed the same diet supplemented with 50 and 100 ppm inorganic $\mathrm{Cu}$ (copper sulfate, $\mathrm{CuSO}_{4}$ ), while diets of the $4^{\text {th }}$ and $5^{\text {th }}$ groups were supplied with 50 and 100 ppm organic $\mathrm{Cu}$ (copper methionine Cu-Met), and then the $6^{\text {th }}$ and $7^{\text {th }}$ groups have been fed diets with 50 and 100 ppb nano inorganic copper (Cu-NP), respectively. Birds of all treatments were reared in similar hygienic and managerial conditions. Feed and fresh water were offered for ad libitum. The basal diet was formulated according to the strain management guide as listed in Table 1.

\section{Housing and management}

Chicks were housed in breeding pens in semiclosed system house. They exposed to a standard light program that recommended for broiler chicks production under commercial conditions, where a $23 \mathrm{~h}$ light was supplied during the first week of age followed by $20 \mathrm{~h}$ light from the second week until the end of the fattening period. The brooding temperature (indoor) was $33 \mathrm{C}^{\circ}$ in the first week, then declined gradually to reach 30-27 and 24-21 $\mathrm{C}^{\circ}$ during the second week and from 3 to 6 week of age, respectively. 

supplementation of different copper forms

Table 1. Ingredients and calculated analysis of the basal 'diets

\begin{tabular}{|c|c|c|}
\hline (\%) & $\begin{array}{l}\text { Starter } \\
\text { phase } \\
\text { (8- 21 } \\
\text { days) }\end{array}$ & $\begin{array}{c}\text { Growing } \\
\text { (22 to } 35 \\
\text { days ) }\end{array}$ \\
\hline Yellow Corn & 57.60 & 61.00 \\
\hline Soybean Meal (48\%) & 29.50 & 26.00 \\
\hline Corn gluten meal (60\%) & 5.20 & 6.00 \\
\hline Soy oil & 1.10 & 2.70 \\
\hline Full fat soya bean & 2.00 & 0.00 \\
\hline Mono calcium Phosphate & 1.50 & 1.65 \\
\hline Lime stone & 1.90 & 1.50 \\
\hline Choline Chloride & 0.10 & 0.10 \\
\hline Sodium Bicarbonate & 0.20 & 0.20 \\
\hline Salt $(\mathrm{NaCl})$ & 0.20 & 0.20 \\
\hline $\mathrm{DL}$-methionine & 0.10 & 0.10 \\
\hline L-lysine & 0.30 & 0.25 \\
\hline Broiler Premix * & 0.30 & 0.30 \\
\hline Total \% & 100 & 100 \\
\hline \multicolumn{3}{|c|}{ Calculated analysis ( DM basis) } \\
\hline $\mathrm{CP} \%$ & 22.9 & 21.4 \\
\hline $\mathrm{ME}(\mathrm{kcal} / \mathrm{kg})$ ** & 3042 & 3147 \\
\hline Ether extract & 4.10 & 4.40 \\
\hline Calcium & 1.05 & 0.90 \\
\hline Av. Phosphorus & 0.51 & 0.43 \\
\hline Methionine & 0.50 & 0.46 \\
\hline Lysine & 1.40 & 1.23 \\
\hline Methionine + cysteine & 0.98 & 0.89 \\
\hline
\end{tabular}

* Each kg premix contains: vit. A (12 I.U.), vit. D3 (5 I.U.), vit. E (75 I.U.), vit. K menadione (2 mg), vit. B1 (2 mg), vit. B2 (6 mg), vit. B6 (4 mg), vit. B12 (0.016 mg), Pantathenic acid (13 mg), Nicotinic acid (55 mg), Folic acid (2 mg), Biotin (0.2 mg), Copper (16 mg), lodine (1.25 mg), Iron (40 $\mathrm{mg}$ ), Manganese (120 mg), Zinc (100 mg), Selenium (0.3 $\mathrm{mg}) .{ }^{* *} \mathrm{ME}=$ Metabolizable Energy

\section{Data collection}

Performance parameters including individual live body weight (LBW, g), gain of weight (BWG, g), and feed consumption (FI, g) were recorded weekly throughout the trial period (7-35 d of age). For each replicate within treatment groups, feed / gain ratio (FCR) was calculated according to the formula:

$$
F C R=F I(g) / B W G(g) .
$$

Economic efficiency of experimental diets was estimated (Zeweil, 1996) as the ratio between income and total feed cost during the experimental growth period. The price of the fed diets and Cu supplements was calculated according to the local market price at the same time of the experiment in 2019 by the Egyptian pound (L.E.). Economic efficiency $(\%)=(\text { Net revenue/Total feed cost })^{*} 100$.

Net revenue $=$ Total revenue - Total feed cost. European production efficiency index (EPEI, production index) was calculated to Hubbard broiler management manual as follows.

$$
\text { EPEI }=\frac{\text { BW }(\mathrm{kg}) x \text { SR }}{\text { PP } x \text { FCR }} x 100
$$

Where:

BW $=$ Body weight $(\mathrm{kg}), \mathrm{SR}=$ Survival rate $(100 \%$ mortality), PP = Production period (days), FCR = Feed conversion ratio ( $\mathrm{kg}$ feed / $\mathrm{kg}$ gain)

Apparent digestibility of dry matter, crude protein, fiber, ash and ether extract, were determined by using five birds per treatment that were housed individually in metabolic cages using the procedures reported by Abou-Raya and Galal (1971) with aid of total collection method. Nitrogen, ether extract, crude fiber and ash content of the excreta as well as those of feed were determined according to AOAC (2004).

At slaughtering time, blood samples were withdrawn from six (randomly chosen) chicks / treatment group in two sterilized test tubes. The first one was heparinized tubes for the determination of the hematological parameters. The second non-heparinized tubes were allowed to coagulate at room temperature for $30 \mathrm{~min}$ and then centrifuged at 4000 $\mathrm{rpm} / \mathrm{min}$ for $10 \mathrm{~min}$ then sera were decanted and stored at $-20 \mathrm{C}^{\circ}$ until the biochemical analyses were done by using available commercial kits. Blood glucose concentration $(\mathrm{mg} / \mathrm{dl})$ was determined according to Trinder (1969), total protein (Henry et al 1974), albumin (Doumas, 1971), globulin (Coles, 1974) and its fractions $(\alpha ; \beta$ and $y$-globulins) as described by Bossuyt et al (2003). In addition, further assays was done in terms of serum creatinine and uric acid (Bartles et al 1972), total cholesterol (Stein, 1986), triglycerides (Fossati and Prencipe, 1982), HDL (Lopez-Virella, 1977), while LDL was calculated by the formula of Friedewald et al (1972). Transaminases (ALT and AST) and alkaline phosphatase (ALP) activities were also measured according to Reitman and Frankle (1957) and Bauer (1982), respectively.

The heparinized blood samples were used to determine number of red blood cells, total white blood cells count and differential types. Besides, packed cell volume (\%), Hemoglobin concentration and $\mathrm{CBC}$ indices $(\mathrm{MCH}$ and $\mathrm{MCHC}$ ) were determined with the following equations: 
Mean Corpuscular Hemoglobin $(\mathrm{MCH}, \mathrm{Pg})=$ $\mathrm{Hb} \times 10 /$ Red blood cell

Mean Corpuscular Hemoglobin Concentration $(\mathrm{MCHC})(\mathrm{g} / \mathrm{dl})=\mathrm{Hb} \times 100 /$ Packed cell volume

Total antioxidant capacity was determined according to Koracevic et al (2001), Superoxide dismutase activity (Misra and Fridovich, 1972), Glutathione peroxidase activity (Paglia and Valentine, 1967) and Glutathione activity (Ellman, 1959). Phagocytic activity and index was determined according to Kawahara et al (1991). Phagocytic activity (PA) $=$ Percentage of phagocytic cells containing yeast cells.

Phagocytic index $(\mathrm{PI})=$ Number of yeast cell phagocytized/ Number of phagocytic cells.

Serum immunoglobulins ( $\lg \mathrm{Y}, \lg \mathrm{M}$ and $\lg \mathrm{A})$ were measured by using commercial ELISA kits (Kamiya Biomed. Comp., USA) as reported by Bianchi et al (1995). All measurements were conducted according to the manufacturer's instructions. Lymphocyte transformation test was determined following the method described by Balhaa et al (1985). Serum bactericidal activity against Aeromonas hydrophila strain was determined according to Rainger and Rowley (1993). Serum lysozyme activity was measured with the turbidimetric method described by Engstad et al (1992) and the results are expressed as one unit of lysozyme activity that defined as a reduction in absorbance at $0.001 / \mathrm{min}$. Lysozyme activity $=(A 0-A) / A$.

\section{Bacterial count}

The microbial load of the digestive system was evaluated through measuring total bacterial count and also counting some pathogenic bacteria harboring the intestine such as salmonella, E.coli and proteus spp. according to methods described by ICMSF (1980).

\section{Statistical analysis}

Data were subjected to the one way ANOVA procedure using Statistical Analysis System (SAS), 2002, with the following model:

$$
Y i j=\mu+T i+e i j
$$

Where $Y$ is the dependent variable; $\mu$ the general mean; $T$ the fixed effect of $i^{\text {th }}$ treatment and $e$ the random error.

The difference among means was determined using Duncan's new multiple range est (Duncan, 1955) at $\mathrm{P}<0.05$.

\section{RESULTS AND DISCUSSION}

\section{Productive performance traits}

Data of growth performance, economical efficiency and production index are shown in Table (2). Results revealed that supplementation of different forms and levels of $\mathrm{Cu}$ has resulted in a significant $(p \leq 0.05)$ increase in body weight (BW) at $35 \mathrm{~d}$ of age and body weight gain (BWG) from 7-35 d, when compared with the control group. However, the best results were achieved by Cu-Meth and Cu-NP addition than the other inorganic or non -supplemented control group. Moreover, feed conversion ratio (FCR) of broiler chicks that fed the experimental diets supplied with different forms and levels of $\mathrm{Cu}$ displayed better values when comparison with the control group, with significant differences being obtained for broilers fed Cu-Meth and $\mathrm{Cu}-\mathrm{Np}$ - supplemented diets. They had significantly $(p \leq 0.05)$ better economic efficiency and production index compared with the control group, but the best values were recorded for groups that fed on organic and nano $\mathrm{Cu}$. These observations are in the line with those of Luo et al (2005), Paik, (2001), Surai (2016), El-kazaz and Hafez (2020) and El-Ghalid et al (2019) who found that all sources and levels of $\mathrm{Cu}$ supplementation created significant increases in body weight at $35 \mathrm{~d}$ of age when compared with the non- supplemented group, with significant differences shown by those fed organic copper.

The significant increases in LBW and BWG that observed in the present study could be attributed to the role of copper in skeletal muscles building via modulating synthesis and release of some anabolic hormones, enhancing nitrogen retention and / or muscle fibers hypertrophy. This holds true as Arias and Koutsos (2006) revealed that $\mathrm{Cu}$ works to increase muscle mass in the body through clear mechanisms as it regulates the balance of nitrogen in the body and increase the availability of amino acids for absorption in the intestines (Scott et al 2018) which is essential in the process of building protein inside the cells and the result of increasing the amount of muscle in the body will positively reflected on body weight as it has an important role in the oxidation of lysine. These findings confirm and support our results. Moreover, Zhou et al (1994) cited the mechanism(s) by which copper can exert its effect on growth. Such mechanisms are: 1) its antibacterial effect which undoubtedly change the microflora populations in the digestive tract; 2) induce mitogenesis activity; 3) stimulate growth hormone synthesis release from adenohypophysis 

supplementation of different copper forms

Table 2. Effect of different copper forms on productive performance of broiler chicks

\begin{tabular}{|l|l|l|l|l|c|c|c|c|}
\hline \multicolumn{2}{|c|}{ Parameter } & $\begin{array}{c}\text { LBW } \\
\mathbf{7} \mathbf{d}(\mathbf{g})\end{array}$ & $\begin{array}{c}\text { LBW } \\
\mathbf{3 5} \mathbf{d} \\
\mathbf{( g )}\end{array}$ & $\begin{array}{c}\text { BWG } \\
\mathbf{7 - 3 5 d} \\
\mathbf{( g )}\end{array}$ & $\begin{array}{c}\text { FI } \\
\mathbf{7 - 3 5 d} \\
\mathbf{( g )}\end{array}$ & $\begin{array}{c}\text { FCR } \\
\mathbf{7 - 3 5 d} \\
\mathbf{( g )}\end{array}$ & $\begin{array}{c}\text { Economic } \\
\text { efficiency }\end{array}$ & $\begin{array}{c}\text { Production } \\
\text { index }\end{array}$ \\
\hline Control & $\mathbf{0} \mathbf{p p m}$ & $\mathbf{2 0 1}$ & $\mathbf{1 7 8 0 ^ { \mathrm { c } }}$ & $\mathbf{1 5 8 0 ^ { \mathrm { c } }}$ & $\mathbf{3 1 3 2}$ & $\mathbf{1 . 9 8 ^ { \mathrm { a } }}$ & $\mathbf{0 . 8 8 0 ^ { \mathrm { c } }}$ & $\mathbf{1 4 0}^{\mathrm{c}}$ \\
\hline CuSO4 & $50 \mathrm{ppm}$ & 202 & $1890^{\mathrm{b}}$ & $1690^{\mathrm{b}}$ & 3141 & $1.85^{\mathrm{b}}$ & $1.24^{\mathrm{b}}$ & $155^{\mathrm{b}}$ \\
& $100 \mathrm{ppm}$ & 200 & $1900^{\mathrm{b}}$ & $1700^{\mathrm{b}}$ & 3009 & $1.8^{\mathrm{b}}$ & $1.31^{\mathrm{b}}$ & $159^{\mathrm{b}}$ \\
\hline Cu-Met & $50 \mathrm{ppm}$ & 201 & $2200^{\mathrm{a}}$ & $1980^{\mathrm{a}}$ & 3198 & $1.70^{\mathrm{c}}$ & $1.73^{\mathrm{a}}$ & $180^{\mathrm{a}}$ \\
& $100 \mathrm{ppm}$ & 202 & $2290^{\mathrm{a}}$ & $2020^{\mathrm{a}}$ & 3190 & $1.60^{\mathrm{c}}$ & $1.80^{\mathrm{a}}$ & $180^{\mathrm{a}}$ \\
\hline Nano-Cu & $50 \mathrm{ppb}$ & 203 & $2400^{\mathrm{a}}$ & $1990^{\mathrm{a}}$ & 3181 & $1.60^{\mathrm{c}}$ & $1.96^{\mathrm{a}}$ & $170^{\mathrm{a}}$ \\
& $100 \mathrm{ppb}$ & 200 & $2410^{\mathrm{a}}$ & $2300^{\mathrm{a}}$ & 3200 & $1.60^{\mathrm{c}}$ & $1.90^{\mathrm{a}}$ & $169^{\mathrm{a}}$ \\
\hline SEM & & 1.447 & 4.975 & 45.82 & 39.11 & 0.064 & 9.98 & 11.9 \\
\hline P-Value & & 0.987 & 0.004 & 0.007 & 0.0801 & 0.0001 & 0.001 & 0.002 \\
\hline
\end{tabular}

$a, b, c$ different letters in the same column are significantly different at $p \leq 0.05$.SEM=Standard error of means.

and increasing $\mathrm{GH}$-gene expression (LaBella et al 1973); 4) increased neuropeptide $Y$ formation and release (Tsou et al 1977); 5) modulation of regulatory peptides action (Eipper and Mains 1988) and 6 ) as an element in the human growth factor (lamin) specific for wound healing (Parkart, 1987).

\section{Apparent digestibility of nutrients (ADN)}

Table 3 demonstrates the influence of different forms of copper on the AND of chicks. It is clear that different forms of $\mathrm{Cu}$ had significantly affected the coefficient of digestibility of crude protein, ether extract and dry matter. Thus, the basal diet supplemented with each of Cu-organic, Cu-inorganic and $\mathrm{Cu}$ nano forms significantly increased their digestibility compared to the control. However, there were no significant effects of different $\mathrm{Cu}$ sources on crude fiber and Apparent Ash retention digestibility. Our findings are in accordance with those reported by Wu et al (2014 and 2018).

\section{The blood hematological criteria}

The blood hematological criteria of $35 \mathrm{~d}$ old chicks that fed the basal diet supplied with different forms and levels of $\mathrm{Cu}$ are shown in Table 4.

Different forms of $\mathrm{Cu}$ supplementation improved RBC's, Hb, PCV, MCV and $\mathrm{MCH}$ nut not MCHC concentration of chicks compared with the control group. Data concerning the effects of $\mathrm{Cu}$ sources on the total WBCs and its differential counts of chicks at 35 day of age are shown in Table 5. The different sources of $\mathrm{Cu}$ had improved the WBC's and Lym- phocytes (L, \%) only. However, the differences between treatments in the percentages of Monocytes, Basophils, Eosinophils, Heterophils $(\mathrm{H})$ and $\mathrm{H} / \mathrm{L}$ ratio were not significant.

These findings are in agreement with those of Makaraski and Zdura (2006) found that the higher number of RBCs recorded with dietary Cu-supplemented may be due to $\mathrm{Cu}$ involvement in hemoglobin synthesis. They concluded that supplementing turkey's diet with $\mathrm{Cu}$ lysine chelate has a significant effect on the level of hematological indices. Moreover, addition of both antibiotics and $\mathrm{Cu}$ products resulted in reduced levels of RBC and HCT paralleled to RBC and HCT in the control group. The MCV value was decrease in the $\mathrm{Cu}$-supplemented groups paralleled with that in control group (Kim et al 2011).

The observed changes in blood hematology in response to $\mathrm{Cu}$-supplementation could be explained by the relationship between copper and iron metabolism. It is well known that $\mathrm{Cu}$ is not actually a constituent of hemoglobin, but it is a main element in certain specific blood proteins, mainly ceruloplas$\mathrm{min}$, which is responsible with the release of iron from the cells into the plasma. In this concern, Fox (2003) reported that copper deficiency retarded the ability of animals to absorb iron, mobilize it from the tissues to be utilized in hemoglobin formation. Moreover, $\mathrm{Cu}$ has a significant and direct impact in the process of RBCs formation, as it interferes in the rate of and amount of iron absorbed into the body and its incorporation to hemoglobin. Also, $\mathrm{Cu}$ is an important element of other blood proteins, i.e. erythrocuprein which present in the erythrocytes, where 
Table 3. Effect of different cupper forms on the apparent digestibility of the nutrients of broiler chicks

\begin{tabular}{|c|c|c|c|c|c|c|c|c|c|}
\hline \multirow{2}{*}{\begin{tabular}{|l} 
Treatment \\
Parameter
\end{tabular}} & \multirow{2}{*}{ 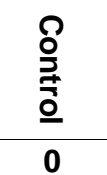 } & \multicolumn{2}{|c|}{ CuSO4 } & \multicolumn{2}{|c|}{ Cu-Meth } & \multicolumn{2}{|c|}{ Nano - Cu } & \multirow{2}{*}{ SEM } & \multirow{2}{*}{ P-Value } \\
\hline & & 50 & 100 & 50 & 100 & 50 & 100 & & \\
\hline Crude protein & $69.11^{\mathrm{c}}$ & $73.3^{b}$ & $75.9^{b}$ & $77.0^{\mathrm{a}}$ & $80.1^{\mathrm{a}}$ & $81.9^{a}$ & $82.9^{a}$ & 1.99 & 0.001 \\
\hline Ether extract & $70.1^{\mathrm{b}}$ & $66.9^{b}$ & $82.3^{a}$ & $85.6^{a}$ & $83.3^{\mathrm{a}}$ & $83.3^{a}$ & $82.6^{a}$ & 11.9 & 0.0090 \\
\hline Crude fiber & 17.1 & 19.6 & 18.63 & 19.5 & 20.8 & 19.62 & 19.5 & 1.19 & 0.081 \\
\hline Apparent Ash retention,\% & 33.2 & 39.7 & 39.0 & 38.8 & 37.8 & 37.9 & 37.8 & 8.34 & 0.156 \\
\hline Dry matter & $64.9^{c}$ & $70.1^{b}$ & $71.9^{b}$ & $75.5^{\mathrm{a}}$ & $74.9^{\mathrm{a}}$ & $77.9^{a}$ & $77.5^{\mathrm{a}}$ & 10.72 & 0.001 \\
\hline
\end{tabular}

$\mathrm{a}, \mathrm{b}, \mathrm{c}$ different letters in the same row are significantly different at $\mathrm{p} \leq 0.05 . \mathrm{SEM}=$ Standard error of means

Table 4. Effect of different cupper forms on hematological parameters of broiler chicks

\begin{tabular}{|c|c|c|c|c|c|c|c|c|c|}
\hline \multirow{2}{*}{$\begin{array}{l}\text { Treatment } \\
\text { Parameter }\end{array}$} & \multirow{2}{*}{ 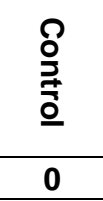 } & \multicolumn{2}{|c|}{ CuSO4 } & \multicolumn{2}{|c|}{ Cu-Met } & \multicolumn{2}{|c|}{ Nano - Cu } & \multirow{2}{*}{ SEM } & \multirow{2}{*}{ P-Value } \\
\hline & & 50 & 100 & 50 & 100 & 50 & 100 & & \\
\hline RBC's $\left(10^{6} / \mathrm{mm}^{3}\right)$ & $1.56^{b}$ & $1.76^{\mathrm{ab}}$ & $1.90^{\mathrm{a}}$ & $1.86^{a}$ & $1.96^{a}$ & $1.86^{\mathrm{a}}$ & $1.86^{\mathrm{a}}$ & 0.0534 & 0.0006 \\
\hline $\mathrm{Hb}(\mathrm{g} / 100 \mathrm{ml})$ & $9.66^{c}$ & $11.9^{b}$ & $10.3^{b}$ & $15.9^{a}$ & $14.66^{a}$ & $14.6^{a}$ & $16.9^{a}$ & 0.7968 & 0.0115 \\
\hline PCV \% & $33.6^{b}$ & $37.3^{\mathrm{b}}$ & $39.9^{a b}$ & $42.6^{a}$ & $41.6^{\mathrm{a}}$ & $41.6^{a}$ & $43.9^{a}$ & 0.9920 & 0.0013 \\
\hline MCVum $^{3}$ & $215^{b}$ & $212^{\mathrm{b}}$ & $210^{b}$ & $229^{a}$ & $212^{b}$ & $223^{a}$ & $236^{a}$ & 11.9 & 0.001 \\
\hline $\mathrm{MCH}(\mathrm{pg})$ & $61.9^{b}$ & $67.6^{\mathrm{b}}$ & $54.2^{\mathrm{b}}$ & $85.5^{\mathrm{a}}$ & $74.8^{a}$ & $80.1^{\mathrm{a}}$ & $90.9^{a}$ & 13.9 & 0.006 \\
\hline $\mathrm{MCHC}(\mathrm{g} / \mathrm{dl})$ & 28.75 & 31.9 & 25.8 & 37.3 & 35.2 & 35.0 & 38.5 & 9.99 & 0.093 \\
\hline
\end{tabular}

a,b,c different letters in the same row are significantly different at $p \leq 0.05$.SEM=Standard error of means

Table 5. Effect of different cupper forms on the differential count of leukocytes

\begin{tabular}{|c|c|c|c|c|c|c|c|c|c|}
\hline Treatment & $\stackrel{\varrho}{\stackrel{2}{2}}$ & $\mathrm{Cu}$ & 04 & Cu-I & & Nanc & $-\mathrm{Cu}$ & SEM & P-Value \\
\hline Parameter & 0 & 50 & 100 & 50 & 100 & 50 & 100 & & \\
\hline WBC's $\left(10^{3} / \mathrm{cmm}^{3}\right)$ & $20.66^{c}$ & $24.33^{b}$ & $25.33^{b}$ & $26.66^{\mathrm{ab}}$ & $29.9^{a}$ & $29.6^{a}$ & $30.9^{a}$ & 0.7126 & 0.004 \\
\hline Lymphocytes (\%) & $35.3^{c}$ & $41.3^{b}$ & $42.6^{\mathrm{b}}$ & $41.1^{\mathrm{b}}$ & $41.6^{b}$ & $45.4^{\mathrm{a}}$ & $41.9^{b}$ & 0.6666 & 0.001 \\
\hline Monocytes (\%) & 11.9 & 10.4 & 10.6 & 16.3 & 17.3 & 13.3 & 10.6 & 0.3563 & 0.441 \\
\hline Eosinophils, (\%) & 12.8 & 14.2 & 13.3 & 11.4 & 13.6 & 10.1 & 13.3 & 0.6546 & 0.540 \\
\hline Heterophils, (\%) & 39.6 & 33.9 & 32.8 & 30.8 & 26.9 & 30.9 & 33.9 & 0.765 & 0.334 \\
\hline Basophils, (\%) & 0.33 & 0.33 & 0.70 & 0.33 & 0.61 & 0.30 & 0.33 & 0.6546 & 0.138 \\
\hline $\mathrm{H} / \mathrm{L}$ ratio & 1.12 & 0.82 & 0.76 & 0.75 & 0.70 & 0.75 & 0.80 & 0.987 & 0.099 \\
\hline
\end{tabular}

$a, b, c$ Means in the same row with different letters differ significantly ( $p \leq 0.05)$ SEM=Standard error of the mean.

it plays a role in oxygen metabolism. This assumption confirm the findings of Winnica (2008) who reported that the higher number of RBCs recorded with Cu-supplements to diet is due to the participation of $\mathrm{Cu}$ in the process of hemoglobin synthesis.
Also, studies by Makaraski and Zdura (2006) declared that enriching turkey's diet with Copper- lysine chelate has significant effects on the level of hematological measurements of blood which support our results. 


\section{Biochemical constituents of blood}

\section{Protein profile}

Total serum protein of chicks fed $\mathrm{Cu}$ - supplemented diets is illustrated in Table 6. Different forms of $\mathrm{Cu}$ supplementation significantly increased total protein, total globulin and $\mathrm{y}-$-Globulin concentrations than the control group. Organic and nano $\mathrm{Cu}$ resulted in the highest total protein globulin concentrations and $Y$-Globulin of chicks. However the effect of different sources of $\mathrm{Cu}$ supplementation on serum albumin, $\alpha$-globulin and $\beta$-globulin of chicks was not significant. These findings are in agreement with those of El-Ghalid et al (2019), Chowdhury et al (2004), Kim et al (2011) and Reham, (2018) through clear mechanisms as the copper regulates the balance of nitrogen in the body and increase the availability of amino acids for absorption in the intestines (Pastorelli et al 2010) which is essential in the process of building protein inside the cells and the result of increasing the amount of muscle in the body will positively reflected on body weight as it has an important role in the oxidation of lysine. This result was consistent with what was mentioned by a number of researchers (Scott et al 2018).

\section{Blood glucose and thyroid hormones}

The blood glucose and thyroid hormones of chicks fed the basal diet supplemented with different sources of $\mathrm{Cu}$ are shown in Table 7. Different sources of $\mathrm{Cu}$ supplementation significantly increased serum level of thyroxin $\left(T_{4}\right)$, triiodothyronine $\left(\mathrm{T}_{3}\right)$ and glucose than the control group. Organic and nano $\mathrm{Cu}$ supplementation resulted in a significant increase in blood glucose, T3 and T4 than the control group and Cu inorganic. These findings are in agreement with those of El-Ghalid et al (2019), Chowdhury et al (2004), Kim et al (2011) and Reham, (2018).

\section{Lipid profile}

Data concerning the effects of $\mathrm{Cu}$ forms on the lipid profile of chicks are presented in Table 8. It appears that serum concentrations of total lipids, cholesterol, triglycerides and low-density lipoprotein (LDL) were significantly reduced by copper inclusion in the diets. Furthermore, addition of organic and nano organic sources of $\mathrm{Cu}$ to the feed had a significantly lower total lipids and LDL in blood plasma compared with the $\mathrm{Cu}$ inorganic and control group. The hypolipedimic effect of CuNP was more obvious than the other forms in this respect, especially when serum cholesterol is taken as the criteria of response. However, high density lipoprotein level
(HDL) was not affected in all treatments. Our findings are nearly similar to those observed by Ognik et al (2018), El-Ghalid et al (2019), Chowdhury et al (2004), Kim et al (2011) and Reham (2018). In this respect, Sevcikova et al (2003) observed that cholesterol concentration was declined by $24.9 \%$ in $\mathrm{Cu}$ - glycine chelate fed group compared to the control one. Also, Aksu et al (2010) observed a drop in cholesterol and LDL fraction levels with a raise in HDL level in the plasma of chickens consumed rations containing different organic forms of Zinc, Copper and Manganese. Mondal et al (2007) fed broiler chickens on diets contained 200 or $400 \mathrm{mg}$ $/ \mathrm{kg}$ from organic and inorganic copper salts, they declared that the first level $(200 \mathrm{mg} / \mathrm{Kg}$ ) has a lowering effect on serum cholesterol, while the high inclusion level $(400 \mathrm{mg} / \mathrm{kg})$ resulted in higher level of HDL. This was not observed by Konjifca et al (1997) that a supplementation of $\mathrm{Cu}$ in an organic form leads to a higher content of cholesterol and HDL fraction. The hypo-cholesterolemic - mechanism of copper sulfate was firstly established in rats. Since, Kim et al (1992) showed that liver copper results in reducing hepatic reduced glutathione concentration which inhibits the enzymatic activity of HMG-COA-reductase, the rate-limiting step in the synthesis of mevalonate, and finally reduced cholesterol biosynthesis. Bakalli et al (1995) verified that such mechanism is also operative in the chicken where they observed that a high dietary copper level $(250 \mathrm{mg} / \mathrm{kg})$ fed to broiler chicks decreased blood reduced glutathione concentration and subsequently reduced plasma total cholesterol. Similarly, the observed increase in HDL level with levels of 50 and $100 \mathrm{mg} / \mathrm{kg}$ diet is in accordance with the findings by Pearce et al (1983) and Lien et al (2004) who found dietary supplemental copper to reduce serum VLDL-cholesterol and increase HDLcholesterol of laying hens. Similar results were also reported by Bakalli et al (1995) and Hamdi et al (2018) in broiler chickens, and in Japanese quail (Reham, 2018) The observed increase in serum HDL-cholesterol might be attributed to the high dissociation rate of cholesterol to be esterified by transformation of the long chain fatty acid pattern. It is also suggested that the triglycerides-lowering effect of Cu supplementation be mediated via its lowering impact on fatty acid synthetase (FAS) enzyme activity which in turn resulted in a reduction in the synthesis of fatty acid from Acetyl COA and finally decreasing triglycerides biosynthesis. This mechanism of $\mathrm{Cu}$ to reduce plasma triglycerides level was evidenced by the results of Qureshi et al (1983) and Konjufca et al (1997) who illustrate that FAS activity was significantly suppressed by copper feeding. 
Table 6. Effect of different cupper forms on blood protein fraction of broiler chicks

\begin{tabular}{|c|c|c|c|c|c|c|c|c|c|}
\hline \multirow{2}{*}{\begin{tabular}{|l} 
Treatment \\
Parameter \\
\end{tabular}} & \multirow{2}{*}{$\begin{array}{c}\text { 을 } \\
\frac{2}{7} \\
\text { 으 } \\
0\end{array}$} & \multicolumn{2}{|c|}{ CuSO4 } & \multicolumn{2}{|c|}{ Cu-Met } & \multicolumn{2}{|c|}{ Nano - Cu } & \multirow{2}{*}{ SEM } & \multirow{2}{*}{ P-Value } \\
\hline & & 50 & 100 & 50 & 100 & 50 & 100 & & \\
\hline Total protein (g/dl) & $4.96^{c}$ & $5.43^{b}$ & $5.83^{b}$ & $6.42^{a}$ & $6.11^{a}$ & $6.34^{\mathrm{a}}$ & $6.64^{a}$ & 0.218 & 0.0026 \\
\hline Albumin (g/dl) & 2.73 & 2.33 & 2.61 & 1.96 & 2.00 & 2.01 & 2.23 & 0.130 & 0.1091 \\
\hline Globulin (g/dl) & $2.23^{c}$ & $3.20^{\mathrm{b}}$ & $3.23^{b}$ & $4.46^{a}$ & $4.11^{a}$ & $4.33^{\mathrm{a}}$ & $4.41^{\mathrm{a}}$ & 0.271 & 0.0025 \\
\hline$\alpha-g l o b u l i n(m g / d l)$ & 0.531 & 0.730 & 0.800 & 0.632 & 0.501 & 0.800 & 0.900 & 0.081 & 0.13 \\
\hline$\beta-$ globulin (mg/dl) & 0.742 & 0.461 & 0.660 & 0.700 & 0.611 & 0.716 & 0.613 & 0.051 & 0.492 \\
\hline y -Globulin (mg/dl) & $0.961^{c}$ & $1.99^{b}$ & $1.76^{b}$ & $2.93^{a}$ & $2.99^{a}$ & $2.89^{a}$ & $2.33^{a}$ & 0.302 & 0.0056 \\
\hline
\end{tabular}

a,b,c Means in the same row with different letters differ significantly $(p \leq 0.05)$ SEM=Standard error of the mean

Table 7. Effect of different cupper forms on blood glucose and thyroid hormones concentrations of broiler chicks

\begin{tabular}{|c|c|c|c|c|c|c|c|c|c|}
\hline Treatment & $\stackrel{ᄋ}{\rho}$ & CuSC & ng/kg & & & Nan & $-\mathrm{cu}$ & SFM & مإla \\
\hline Parameter & 0 & 50 & 100 & 50 & 100 & 50 & 100 & & \\
\hline Glucose (mg/dl) & $166^{c}$ & $179^{b}$ & $177^{b}$ & $191^{a}$ & $189^{a}$ & $181^{a}$ & $187^{a}$ & 1.70 & 0.004 \\
\hline T3 (ng / ml) & $2.05^{c}$ & $2.13^{b}$ & $2.22^{b}$ & $2.41^{a}$ & $2.33^{a}$ & $2.49^{a}$ & $2.35^{\mathrm{a}}$ & 0.021 & 0.005 \\
\hline T4 (ng / ml) & $11.1^{\mathrm{b}}$ & $12.2^{b}$ & $13.2^{b}$ & $16.1^{\mathrm{a}}$ & $17.2^{\mathrm{a}}$ & $15.4^{\mathrm{a}}$ & $17.4^{\mathrm{a}}$ & 0.029 & 0.008 \\
\hline
\end{tabular}

$a, b, c$ Means in the same row with different letters differ significantly $(p \leq 0.05)$ SEM=Standard error of the mean

Table 8. Effect of different cupper forms supplementation on lipids profile of broiler chicks

\begin{tabular}{|c|c|c|c|c|c|c|c|c|c|}
\hline \multirow{2}{*}{\begin{tabular}{|l} 
Treatment \\
Parameter \\
\end{tabular}} & \multirow{2}{*}{ 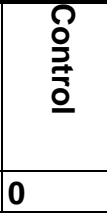 } & \multicolumn{2}{|l|}{ CuSO4 } & \multicolumn{2}{|c|}{ Cu-Met } & \multicolumn{2}{|c|}{ Nano - cu } & \multirow[t]{2}{*}{ SEM } & \multirow{2}{*}{ P-Value } \\
\hline & & 50 & 100 & 50 & 100 & 50 & 100 & & \\
\hline Total Lipids (mg/dl) & $730^{a}$ & $620^{b}$ & $600^{b}$ & $520^{c}$ & $520^{c}$ & $540^{c}$ & $510^{c}$ & 1.99 & 0.001 \\
\hline Cholesterol (mg/dl) & $216^{a}$ & $202^{b}$ & $207^{b}$ & $212^{b}$ & $207^{b}$ & $188^{c}$ & $192^{c}$ & 2.63 & 0.039 \\
\hline Triglycerides $(\mathrm{mg} / \mathrm{dl})$ & $188^{a}$ & $171^{b}$ & $175^{b}$ & $175^{\mathrm{b}}$ & $174.3^{\mathrm{b}}$ & $175^{\mathrm{b}}$ & $174^{b}$ & 1.16 & 0.001 \\
\hline HDL (mg/dl) & 48.1 & 48.7 & 50.6 & 49.3 & 53.3 & 54.7 & 52.6 & 1.36 & 0.113 \\
\hline LDL (mg/dl) & $130.0^{a}$ & $119.0^{b}$ & $121.0^{b}$ & $127.0^{\mathrm{b}}$ & $119.0^{\mathrm{b}}$ & $98.3^{c}$ & $104^{c}$ & 2.76 & 0.002 \\
\hline
\end{tabular}

$a, b, c$ Means in the same row with different letters differ significantly $(p \leq 0.05)$ SEM=Standard error of the mean 

supplementation of different copper forms

\section{Antioxidative defense indicators}

The role of copper supplements in boosting antioxidants in blood serum of treated broiler chicks is shown in Table 9.

Chicks fed basal diet with different forms of $\mathrm{Cu}$ showed significant increases in the total antioxidants capacity (TAC), GSH activity, GSH and SOD in comparison with those fed the control diet. In addition, dietary organic and Cu-NP inclusion significantly increased TAC and SOD activity than the control and inorganic $\mathrm{Cu}$ - fed groups, respectively. These findings are in agreement with those of Ferrari and Cagliero (1993); Sevcikova et al (2003); Chowdhury et al (2004), Mondal et al (2007), Reham (2018) and El-Ghalid et al (2019). Also, Bakalli et al (1995) and Kaneko et al (1997) sustained the second probability where they stated that copper is well known as a strong oxidizer, being readily associated with free $\mathrm{SH}$-groups, may affect the bioavailability of glutathione because the $\mathrm{Cu}-\mathrm{SH}$ bond cannot easily dissociate. On the other hand, copper in the form of methionine or glycine decreased the level of MDA, which is considered as a reliable indicator for oxidative stress, because of its involvement in the antioxidant defense system leading to potential damage of living cells. (Kim et al 2011). Moreover, Jarosz et al (2018) indicated that SOD activity increased with feeding broiler chickens on diets rich in copper sulfate. It is wellknown that copper has the ability to regulate SOD activity in the tissues of growing animals (Surai 2016). Meanwhile, the excess of dietary copper might be the main reason of high SOD activity in quails fed Cu-supplemented diets (Dameron and Harris 1987; Oztürk and Tarhan, 2001). As a component of the antioxidant enzyme superoxide dismutase, copper has an active role in the body's antioxidant defence against the effects of free radicals, thereby limiting lipid oxidation reactions (Ognik et al 2018).

\section{Immune response indices}

The immunity indicators of chicks from different $\mathrm{Cu}$ treatments are listed in Table 10. Results revealed that $\mathrm{Cu}$ supplemented groups had a significant effect on LA, BA, LTT, PI, PA, IgA, IgM and IgG compared with the control group. Furthermore, additions of organic and nano organic sources of $\mathrm{Cu}$ to the feed increased significantly the levels of PI, PA, IgA and IgG than that from $\mathrm{Cu}$ inorganic and control group. On the other hand, there was insignificant influence of the different sources of $\mathrm{Cu}$ on LA, BA, LTT and IgG. This might support the results of Ferrari and Cagliero (1993); Kim et al (2011; Reham (2018) and El-Ghalid et al (2019), they found a positive impact of amino acid chelates on immune system functions, improving the health state and vitality of chickens.

\section{Bacterial count}

The bacterial count of chicks fed diet supplemented with different forms of $\mathrm{Cu}$ is shown in Table 11. Chicken fed basal diet supplemented with different sources of Cu had significantly increased lactobacillus sp. while different sources of $\mathrm{Cu}$ had significantly lower total bacterial count, Salmonella, E. coli and Proteus chicks. Our results showed significant reduction in the number of pathogenic bacteria, indicating the role of $\mathrm{Cu}$ as a good element to relieve bacterial disorders in the digestive tract of broiler chickens. It is well known that the beneficial bacterial community in the digestive tract could enhance and maintain the structural and functional integrity of the epithelial lining mucosa, and affecting the immune system, as well as preventing the development of intestinal disease in chickens (Chambers and Gang, 2011). In addition, El-Ghalid et al (2019 and Chowdhury et al (2004) showed that copper has a significant impact on the regulation of growth rate in broiler chickens, pathogenic bacteria in the jejunum small intestine were prevented by incremented with $\mathrm{Cu}$ supported by our results. 
Table 9. Effect of different cupper forms on antioxidants enzymes of broiler chicks

\begin{tabular}{|c|c|c|c|c|c|c|c|c|c|}
\hline \multirow{2}{*}{$\begin{array}{c}\text { Treatment } \\
\text { Parameter }\end{array}$} & \multirow{2}{*}{ 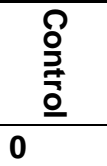 } & \multicolumn{2}{|c|}{ CuSO4 } & \multicolumn{2}{|c|}{ Cu-Met } & \multicolumn{2}{|c|}{ Nano - cu } & \multirow{2}{*}{ SEM } & \multirow{2}{*}{ P-Value } \\
\hline & & 50 & 100 & 50 & 100 & 50 & 100 & & \\
\hline TAC (Mmol/dl) & $411^{\mathrm{c}}$ & $425.3^{b}$ & $417^{b}$ & $443^{a}$ & $433 a$ & $444^{a}$ & $438 a$ & 1.8257 & 0.0013 \\
\hline GPX (U/dl) & $0.213^{b}$ & $0.452^{\mathrm{a}}$ & $0.432^{\mathrm{a}}$ & $0.441^{a}$ & $0.343^{a}$ & $0.413^{a}$ & $0.451^{\mathrm{a}}$ & 0.0152 & 0.0001 \\
\hline GSH (U/dl) & $955^{b}$ & $991^{a}$ & $972^{\mathrm{a}}$ & $970^{a}$ & $994^{a}$ & $968^{a}$ & $981^{a}$ & 5.9441 & 0.0239 \\
\hline SOD $(\mathrm{U} / \mathrm{dl})$ & $222^{c}$ & $241^{b}$ & $243^{b}$ & $256^{a}$ & $258^{a}$ & $255^{\mathrm{a}}$ & $258^{a}$ & 2.4168 & 0.0001 \\
\hline
\end{tabular}

$a, b, c$ Means within the same row with different letters are significantly different $(p \leq 0.05)$.SEM=Standard error of the mean

Table 10. Effect of supplemental different cupper forms on blood plasma immune indices of broiler chicks

\begin{tabular}{|c|c|c|c|c|c|c|c|c|c|}
\hline \multirow{2}{*}{\begin{tabular}{|l} 
Treatment \\
Parameter
\end{tabular}} & \multirow{2}{*}{ 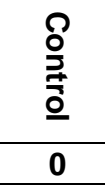 } & \multicolumn{2}{|c|}{ CuSO4 mg/kg } & \multicolumn{2}{|c|}{ Cu-Met $\mathrm{mg} / \mathrm{kg}$} & \multicolumn{2}{|c|}{ Nano - cu } & \multirow{2}{*}{ SEM } & \multirow{2}{*}{ P-Value } \\
\hline & & 50 & 100 & 50 & 100 & 50 & 100 & & \\
\hline LA (IU \%) & $0.111^{b}$ & $0.176^{a}$ & $0.181^{a}$ & $0.183^{a}$ & $0.171^{a}$ & $0.171^{a}$ & $0.173^{a}$ & 0.010 & 0.009 \\
\hline BA ( \% ) & $34.1^{b}$ & $39.6^{a}$ & $38.3^{a}$ & $39.6^{a}$ & $36.6^{a}$ & $38.6^{a}$ & $37.3^{a}$ & 0.967 & 0.005 \\
\hline LTT( \% ) & $20.6^{b}$ & $27.6^{a}$ & $25.3^{a}$ & $27.6^{\mathrm{a}}$ & $27.7^{a}$ & $26.9^{a}$ & $27.6^{\mathrm{a}}$ & 0.854 & 0.007 \\
\hline $\mathrm{PI}(\%)$ & $1.23^{c}$ & $1.45^{b}$ & $1.58^{b}$ & $1.98^{a}$ & $2.09^{a}$ & $1.99^{a}$ & $1.96^{\mathrm{a}}$ & 0.103 & 0.008 \\
\hline PA ( \% ) & $16.9^{c}$ & $17.9^{b}$ & $19.3^{\mathrm{ab}}$ & $21.3 a$ & $22.6 a$ & $21.3 a$ & $22.9^{a}$ & 0.666 & 0.002 \\
\hline $\operatorname{lgA}(\mathrm{mg} / \mathrm{dl})$ & $61.2^{\mathrm{c}}$ & $70.3^{b}$ & $71.6^{b}$ & $80.9^{a}$ & $79.6^{a}$ & $79.6^{a}$ & $79.1^{\mathrm{a}}$ & 1.4853 & 0.0172 \\
\hline $\operatorname{lgM}(\mathrm{mg} / \mathrm{dl})$ & $226^{b}$ & $225^{b}$ & $300^{a}$ & $325^{a}$ & $299^{a}$ & $294^{b}$ & $290^{a}$ & 13.8 & 0.002 \\
\hline $\lg G(\mathrm{mg} / \mathrm{dl})$ & $917.6^{\mathrm{c}}$ & $946^{b}$ & $949^{b}$ & $983^{a}$ & $996^{a}$ & $988^{a}$ & $998^{a}$ & 6.97 & 0.001 \\
\hline
\end{tabular}

a,b,c Means within the same row with different letters are significantly different $(p \leq 0.05) . S E M=S t a n d a r d$ error of the mean.

Table 11. Effect of of different cupper forms on bacterial count of broiler chicks

\begin{tabular}{|c|c|c|c|c|c|c|c|c|c|}
\hline Treatment & $\stackrel{\varrho}{\circ}$ & Cuso & $\mathbf{n g} / \mathbf{k g}$ & $\mathrm{Cu}-\mathrm{Me}$ & $\mathbf{m g} / \mathbf{k g}$ & Nanc & $-\mathrm{cu}$ & FM & P.Value \\
\hline Parameter & 0 & 50 & 100 & 50 & 100 & 50 & 100 & & \\
\hline $\operatorname{TBC}\left(10^{3}\right)$ & $3.27^{a}$ & $1.95^{\mathrm{b}}$ & $2.28^{b}$ & $1.97^{\mathrm{b}}$ & $2.07^{b}$ & $2.17^{\mathrm{b}}$ & $2.09^{b}$ & 0.088 & 0.002 \\
\hline Lactobacillus $\times 10^{3}$ & $1.97^{\mathrm{c}}$ & $2.51^{\mathrm{b}}$ & $2.91^{b}$ & $4.12^{\mathrm{a}}$ & $3.66^{a}$ & $4.82^{\mathrm{a}}$ & $4.53^{a}$ & 0.998 & 0.001 \\
\hline Salmonella $\times 10^{2}$ & $1.01^{\mathrm{a}}$ & $0.808^{b}$ & $0.729^{b}$ & $0.679^{c}$ & $0.629^{c}$ & $0.651^{\mathrm{c}}$ & $0.620^{c}$ & 0.018 & 0.002 \\
\hline E. coli $\times 10^{3}$ & $1.19^{a}$ & $0.903^{b}$ & $0.901^{\mathrm{b}}$ & $0.856^{c}$ & $0.774^{\mathrm{c}}$ & $0.723^{c}$ & $0.792^{c}$ & 0.022 & 0.001 \\
\hline Proteus $\times 10^{2}$ & $0.779^{a}$ & $0.615^{b}$ & $0.601^{b}$ & $0.458^{c}$ & $0.429^{c}$ & $0.428^{c}$ & $0.379^{c}$ & 0.044 & 0.001 \\
\hline
\end{tabular}

a,b,c Means within the same row with different letters are significantly different $(p \leq 0.05) . S E M=S$ tandard error of the mean.

\section{CONCLUSION}

The results can be summarized that the addition of different forms of $\mathrm{Cu}$ inorganic, organic and nano copper to broiler chicken diets improved performance trait. Chickens fed diet with organic and nano copper showed better growth performance than other groups. The use of copper increases he- moglobin synthesis by higher number of RBCs recorded with Cu-supplemented chickens' diet. Different forms of $\mathrm{Cu}$ exert positive impacts on immune profile, antioxidant status and enhanced lipid profile. An increase in protein content may indicate faster biosynthesis of tissue protein, or a slowing down of protein metabolism. Our results showed significant 

supplementation of different copper forms

reduction in the number of pathogenic bacteria ( $S a l-$ monella, E. coli and Proteus), indicating the role of $\mathrm{Cu}$ as a good element to relieve bacterial disorders in the digestive tract of broiler chickens. Further research is necessary to elucidate the effect of organic copper on the immune response and cellular reaction of the digestive system epithelial lining, which helps improve nutrient absorption and disease resistance in chickens.

\section{REFRENCES}

Aboul-Ela S., Abd El-Galil K. and Ali F.A. (2000). Effect of dietary fiber and energy levels on performance of post-weaning rabbits. World Rabbit Sci., 8(Suppl. 1), 61-75.

Abou-Raya A.K. and Galal A.G.H. (1971). Evaluation of poultry feeds in digestion trials with reference to some factors involved. ARE J. Anim. Prod., 11, 207-221.

Aksu D.S., Aksu T. and Ozkay B. (2010). The effect of lower supplementation levels of organically complexed minerals (Zinc, Copper and manganese) versus inorganic forms on hematological and biochemical parameters in broilers. Kafkas, universitesi Veterner Fakultes Dergisi. 16, 553-559.

AOAC (2004). Official methods of analysis. 18th ed., Association of Official Analytical Chemists, Washington, DC, USA.

Arias V.J. and Koutsos E.A. (2006). Effects of copper source and level in intestinal physiology and growth of broiler chickens. Poult. Sci., 85, 999-1007.

Bakalli R.I., Pesti G.M., Ragland W.L. and Konjufca V. (1995). Dietary copper in excess of nutritional requirement reduces plasma and breast muscle cholesterol of chickens. Poult. Sci. 74, 360-365.

Balhaa R.L., Hinz H.H., Luders H. and Siegmann O. (1985). Clinical experiences with the drugs for lymphocyte transformation in chickens and turkey flocks. Tierarztliche Umschau 43, 507508.

Bartles H., Bohmer M. and Heierli C. (1972). Serum creatinine determination without protein precipitation. Clin. Chim. Acta 37, 193-197.

Bauer J.D. (1982). Clinical laboratory methods, 9th edition, pp. 580-581, CV Mosby Co, USA.

Bianchi A.T.J., Moonen-Leusen H.W.M., van der Heijden P.J. and Bokhout B.A. (1995). The use of a double antibody sandwich ELISA and monoclonal antibodies for the assessment of porcine $\lg M$, IgG, and $\lg A$ concentrations. Vet. Immunol. Immunopathol. 44, 309-317.

Bossuyt X., Lissoir B., Mariën G., Maisin D., Vunckx J., Blanckaert N. and Wallemacq P. (2003). Automated Serum Protein Electrophoresis by Capillarys. Clin Chem Lab Med; 41, 704-710.

Chambers J.R. and Gong J. (2011). The intestinal microbiota and its modulation for Salmonella control in chickens. Food Res. Inter., 44, 31493159.

Chowdhury S.D., Paik I.K., Namkung H. and Lim H.S. (2004). Responses of broiler chickens to organic copper fed in the form of coppermethionine chelate. Anim. Feed Sci. Tech., 115, 281-293.

Collins J.F., Prohaska J.R. and Knutson M.D. (2010). Metabolic crossroads of iron and copper. Available at: https://pdfs.semanticscholar.org/399b/741674d 814e28c303a96d71198e870a4f483.pdf

Dameron C.T. and Harris E.D. (1987). Regulation of aortic CuZnsuperoxide dismutase with copper. Effects in vivo. Biochem J. 248, 663668.

Davis G.K. and Mertz W. (1987). Copper. In: W. Mertz (Ed.) Trace Elements in Human and Animal Nutrition. Academic Press, Inc., San Diego, CA. pp. 301-364.

Doumas B. (1971). Colorimetric determination of serum albumin. Clin. Chim. Acta 31, 400-403.

Duncan D.B. (1955). Multiple range and multiple "F" test. Bio- metrics. 11, 1-42.

Eipper B.A. and Mains R.E. (1988). Peptide O-amidation. Annu Rev Physiolog. 50, 333340.

El-Ghalid O.A.H., Ghada M. El-Ashry, Soliman, M.S. and Abd El-Hady A.M. (2019). Effect of dietary sources and levels of copper supplementation on growth performance, blood parameters and slaughter traits of broiler chickens. Egypt. Poult. Sci. 39, 897-912.

Ellman G.L. (1959). Tissue sulfhydryl groups. Arch. Biochem. Biophys., 82, 70-77.

Engstad R.E., Robertsen B. and Frivold E. (1992). Yeast glucan induces increase in lysozyme and complement-mediated haemolytic activity in Atlantic salmon blood. Fish and Shellfish Immun. 2, 287- 297.

Febré N., Silva V., Báez A., Palza H., Delgado K., Aurto I. and Silva V. (2016). Antibacterial activity of copper salts against microorganisms isolated from chronic infected wounds. Rev. Med. Chil 144, 1523-1530. 
Ferrari A. and Cagliero G. (1993). The role of amino acid chelates in overcoming the malabsorption syndrome in poultry (in: The roles of amino acid chelates in animal nutrition). H.D Ashmead. (Ed.)

Fossati P. and Prencipe L. (1982). Serum triglycerides determined colorimetrically with an enzyme that produces hydrogen peroxide. Clin. Chem. 28, 2077-2080.

FOX P.L. (2003). The copper-iron chronicles. The story of an intimate relationship. Biometals 16, 9-40.

Friedewald W.T., Levy R.T. and Frederickson D.S. (1972). Estimation of the concentration of low-density lipoprotein cholesterol in plasma without use of the preparative ultracentrifuge. Clin. Chem. 18, 499-502.

Goel, A.; Bhanja, S.K.; Mehra, M.; Majumder S.; and Pande V. (2013). Effect of in ovo copper and iron feeding on post-hatch growth and differential expression of growth or immunity related genes in broiler chicks. Indian. J. Poult. Sci. 48, 279-285.

Hamdi M., Solà D., Franco R., Durosoy S. Roméo A. and Pérez J.F. (2018). Including copper sulphate or dicopper oxide in the diet of broiler chickens affects performance and copper content in the liver. Anim. Feed Sci. Technol., 237, 89-97.

Hatori Y. and Lutsenko S. (2016). The role of copper chaperone atox1 in coupling redox homeostasis to Intracellular copper distribution. Antioxidants (Basel). 5, $25 . \quad$ doi 10.3390/antiox5030025.

I.C.M.S.F. (1980). International commission on microbiology specification of food micro organisms in food I Salmonella. 2nd Ed Univ. Torento press Toronto, pp. 201-201.

Jarosz L.S., Marek A., Grądzki Z., Kwiecień M. and Kaczmarek B. (2018). The effect of feed supplementation with a copper glycine chelate and copper sulphate on selected humoral and cell mediated immune parameters, plasma superoxide dismutase activity, ceruloplasmin and cytokine concentration in broiler chickens. Anim. Physiol. Anim. Nutr., pp. 326-336.

Kaneko J.J., Harvey J.W. and Bruss M.L. (1997). Clinical Biochemistry of Domestic Animals, 50. Ed., Academic Press, California-USA.

Kawahara E., Ueda T. and Nomura S. (1991). In vitro phagocytic activity of white spotted shark cells after injection with Aermonas salmonicida extracellular products. Gyobo kenkyu, Japan 26, 213-214.
Kim G.B., Seo Y.M., Shin K.S., Rhee A.R., Han J. and Paik I.K. (2011). Effects of supplemental copper-methionine chelate and copper-soy proteinate on the performance, blood parameters, liver mineral content, and intestinal microflora of broiler chickens. J. of Appl. Poult. Res., 20, 21-32.

Kim S., Chao P.Y. and Allen G.D.A. (1992). Inhibition of elevated hepatic glutathione abolishes copper deficiency cholesterolemia. FASEB. J. 6, 2467-2471.

Klasing K.C. (1998). Minerals in Comparative Avian Nutrition. CAB International. New York, USA., pp. 234-276.

Konjufica V.H., Pesti G.M. and Bakalla R.I. (1997). Modulation of cholesterol levels in broiler meat by dietary garlic and copper. Poultry Sci. 76, 1264-1274.

LaBella F., Dular T., Vivian S. and Queen G. (1973). Pituitary hormone releasing or inhibiting activity of metal ions present in hypothalamic extracts. Biochem Biophys. Res. Commun. 52, 786.

Lien T.F., Chen K.L., Wu C.P. and Lu J.J. (2004). Effects of supplemental copper and chromium on the serum and egg traits of laying hens. $\mathbf{B r}$ Poult Sci. 45, 535-539.

Lopez-Virella M.F., Stone S., Eills S. and Collwel J.A. (1977). Determination of HDL-cholesterol using enzymatic method. Clin. Chem. 23, 882884.

Luo X.G., Jl F., Lin Y.X., Ateward F.A., Lu L., Liu B. and Yu S.X. (2005). Effects of dietary supplementation with copper sulfate or tribasic copper chloride on broiler performance, relative copper bioavailability and oxidation stability of vitamin E in feed. Poult. Sci., 84, 888-893.

Makaraski B. and Zadura A. (2006). Influence of copper and lysine chelate on hematological and biochemical component levels in turkey blood. Annals Universities Marie Curie Sklodowska (section EE). 48, 357-363.

Melillo A. (2007). Rabbit clinical pathology. J. Exot. Pet. Med., 16, 135-145.

Misra H.P. and Fridovich I. (1972). The role of superoxide anion in the autoxidation of epinephrine and a simple assay for superoxide dismutase. J. Biol. Chem. 247, 3170-3175.

Mondal M.K., Das T.K., Biswas P., Samanta C.C. and Bairagy B. (2007). Influence of dietary inorganic and organic copper salt and level of soybean oil on plasma lipids, metabolites and mineral balance of broiler chickens. Anim. Feed Sci. Tech., 139, 212-233. 

supplementation of different copper forms

Mroczek-Sosnowska N., Sawosz E., Vadalasetty K.P., Lukasiewicz M., Niemiec J. and Wierzbicki V. (2015). Nanoparticles of copper stimulate angiogenesis at systemic and molecular level. Int. J. Mol. Sci. 16, 4838-4849

Ognik K., Cholewińska E., Sembratowicz I., Grela E.R. and Czech A. (2016). The potential of using plant antioxidants to stimulate antioxidant mechanisms in poultry. World Poultry Sci. J., 72, 1-8.

Ognik K., Sembratowicz I., Cholewińska E., Jankowski J. and Juśkiewicz K. (2018). The effect of administration of copper nanoparticles to chickens in their drinking water on the immune and antioxidant status of the blood. Anim Sci. J. 89, 579-588. https://doi.org/10.1111/asj.12956

ÖZTÜRK-ÜREK R. and Tarhan L. (2001). The purification and characterization of superoxide dismutase from chicken liver. Comp. Biochem. Phys. 128/2, 205-212.

Paik I.K. (2001). Application of chelated minerals in animal production. Asian-australas. J. Anim. Sci., 14(Special Issue), 191-198.

Parkart L. (1987). Biology of Copper Complexes. Clifton (NJ):Humana Press. Chapter 21, lamin: A human growth factor with multiple wound healing properties; pp. 273-282.

Pastorelli G., Rossi R., Cannata S. and Corino C. (2010). Total antiradical activity in male castrated piglets' blood: Reference values. Ital. J. Anim. Sci., 8, 640-642.

Pearce J., Jackson N. and Stevenson M.H. (1983). The effects of dietary intake and of dietary concentration of copper sulphate on the laying domestic fowl: Effects of some aspects of lipid, carbohydrate and amino acid metabolism. Br Poult Sci. 24, 337-348.

Qureshi A.A., Din Z.Z., Abuirmeileh N., Burger W.C. Ahmad Y. and Elson C.E. (1983). Suppression of avian hepatic lipid metabolism by solvent extracts of garlic: impact on serum lipids. J. Nutr. 113, 1746-1755.

Rainger G.E. and Rowley A.F. (1993). Antibacterial activity in the serum and mucus of rainbow trout, Oncorhynchus mykiss following immunization with Aeromonas salmonicida. Fish and shellfish Immun., 3, 475-482.

Reham A.M. (2018). Physiological and antioxidant responses of Japanese quail to dietary copper supplementation. J. Animal and Poultry Prod., Mansoura Univ., Mansoura, Egypt 9, 489495.
Reitman S. and Frankel S. (1957). A Method for determination of enzymatic activities. Am. J. Clin. Path., 287, 56-58.

Sara E. El-kazaz and Mona H. Hafez (2020). Evaluation of copper nanoparticles and copper sulfate effect on immune status, behavior, and productive performance of broilers. J. Adv. Vet. Anim. Res., 7, 16-25.

SAS, Institute (2002). SAS/STAT User's guide statistics. SAS institute INC., Cary. NC, USA.

Scott A., Vadalasetty K.P., Łukasiewicz M., Jaworski S., Wierzbicki M., Chwalibog A. and Sawosz E. (2018). Effect of different levels of copper nanoparticles and copper sulphate on performance, metabolism and blood biochemical profiles in broiler chicken. J. Anim Physiol. Anim Nutr 102, 364-373.

Sevcikova S., Skrivan M., Skrivanova V., Tumova E. and Kovcky M. (2003). Effect of supplementation of copper in copper sulphate and Cuglycine on fatty acid profile in meat of broiler chickens, cholesterol content and oxidation of fat. Czech J. Anim. Sci., 48, 432440.

Sevcikova S., Skrivan M., Skrivanova V., Tumova E. and Kovcky M. (2003). Effect of supplementation of copper in copper sulphate and Cuglycine on fatty acid profile in meat of broiler chickens, cholesterol content and oxidation of fat. Czech J. Anim. Sci., 48, 432440.

Skrivanova V., Skrivan M., Marounek M. and Baran M. (2001). Effect of feeding supplemental copper on performance, fatty acid profile and on cholesterol contents and oxidative stability of meat of rabbits. Archives Anim. Nutr., 54, 329399.

Stein E.A. (1986). Quantitative enzymatic colorimetric determination of total cholesterol in serum or plasma. In: Textbook of Clinical Chemistry. N.W. Tietz, editor. WB. Saunders, Philadelphia, USA, pp. 879-886.

Surai P.F. (2016). Antioxidant systems in poultry biology: superoxide dismutase. J. Anim Res. Nutr. 1, 1-8.

Trinder P. (1969). Enzymatic colorimetric determination of glucose in serum, plasma or urine. Ann. of Clin. Biochem. 6, 24-26.

Tsou R.C., Dailey R.A., McLanhn C.S., Parent A.D., Tindall G.T. and Neill J.D. (1977). Luteinizing hormone releasing hormone (LHRH) levels in pituitary stalk plasma during the preovulatory gonadotropin surge of rabbits. Endocrinology 101, 534-539. 
Velleman S.G. 2007. Muscle development in the embryo and hatchlings. Poult. Sci. 86, 10501054.

Vladimir P., Nollet L. and Gabriel K. (2010). Effect of dietary supplementation of trace elements on the growth performance and their distribution in the breast and thigh muscles depending on the age of broiler chickens. Acta Veterinaria, 79, 203-209.

Wu G., Broniscer A., McEachron T.A., Lu C., Paugh B.S., Becksfort J., Qu C., Ding L., Huether R. and Parker M. (2012). Somatic histone $\mathrm{H} 3$ alterations in pediatric diffuse intrinsic pontine gliomas and non-brainstem glioblastomas. Nat. Genet., 44, 251-253.
Wu G., Diaz A.K., Paugh B.S., Rankin S.L., Ju B., Li Y., Zhu X., Qu C., Chen X. and Zhang J. (2014). The genomic landscape of diffuse intrinsic pontine glioma and pediatric nonbrainstem high-grade glioma. Nat. Genet., 46, 444-450.

Zeweil H.S. (1996). Enzyme supplements to diets growing Japanese quails. Egypt. Poult. Sci. J., 16, 535-557.

Zhou W., Kornegay E.T., Lindemann M.D., Swinkels J.W.G.M., Welton M.K. and Wong E.A. (1994). Stimulation of growth by intravenous injection of copper in weanling pigs. J. Anim. Sci., 72, 2395-2403. 
مجلة اتحاد الجامعات العربية للعلوم الزراعية، جامعة عين شمس، القاهرة، مصر مجلد(28)، عدد(3)، 843-829، 2020

Website: http://ajs.journals.ekb.eg

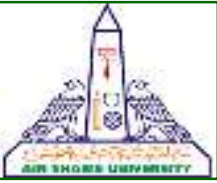

843

الإستجابة الإنتاجية والمناعية لإضافة صور مختلفة من النحاس لبداري التسمين

[60]

إبراهيم الورداني السيد" ${ }^{2}$ - عبد الحميد السيد عبد الحميد² - ايمن محمود السيد² - أسماء شوقي النجار2 2 1- قسم إنتاج الدواجن - كلية الزراعة - جامعة عين شمس - ص.ب 68 - 68 - حدائق شبرا 11241 - 112 - القاهرة - مصرد

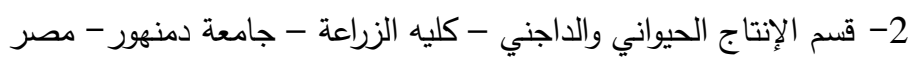

*Corresponding author: asmaa.elnaggar@agr.dmu.edu.eg

Received 30 May, 2020

Accepted 17 August, 2020

التي غذيت علي النحاس العضوي والنانو نحاس مقارنة

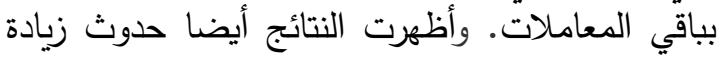
معنوية في مستوي بروتينات الدم والجلوبيولينات المناعية الديات الديات

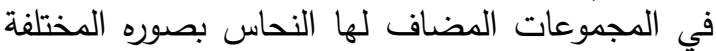

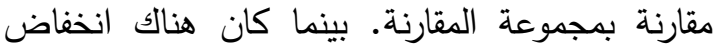
معنوي في مستوي الدهون الكلية في الدم والكوليسترول

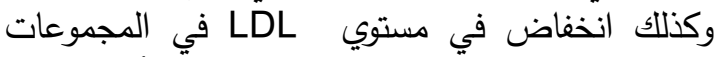

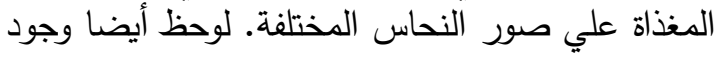

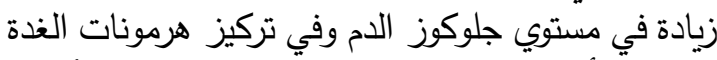

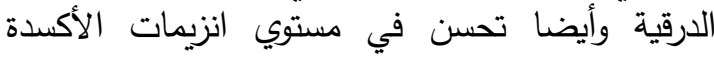

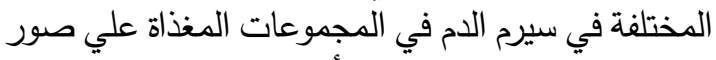

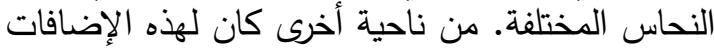

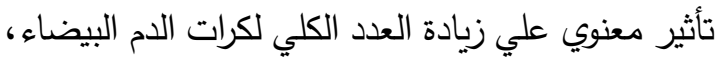

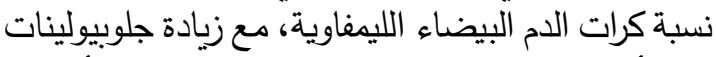

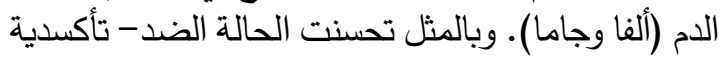

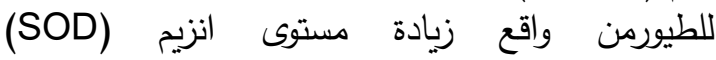
والجلوتاثيون (GSH) والجلوتاثيون بيروكسيديز والقدرة

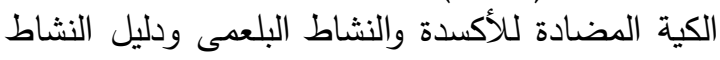

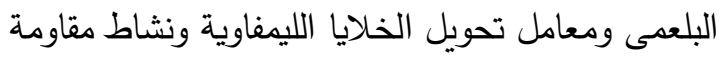

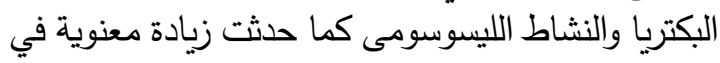

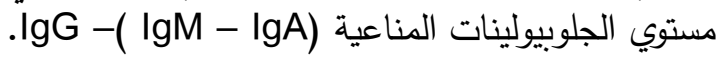

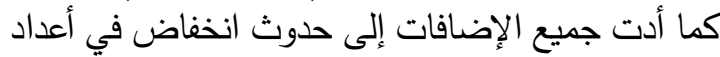

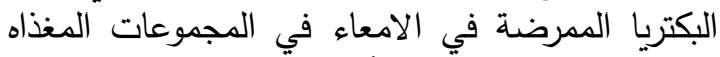

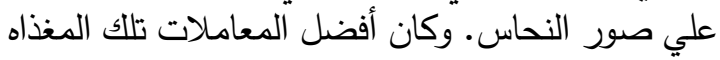

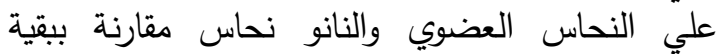

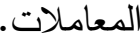

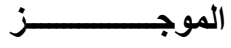

أجريت هذه الدراسة في وحدة بحوث الدواجن بمزرعه الاجنه

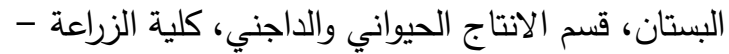

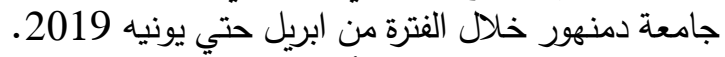

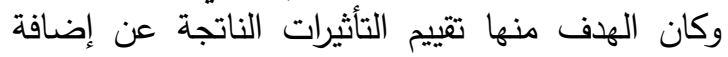

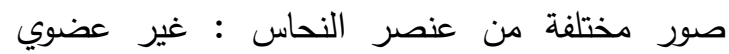
(كبريتات النحاس) عضوي (نحاس- ميثيونين). وكذللك

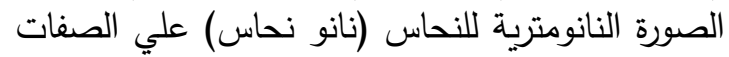

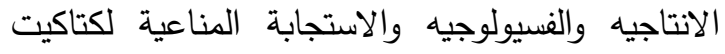

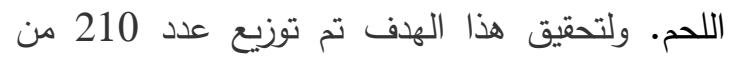

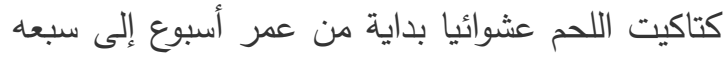

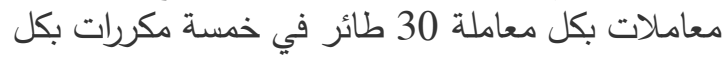

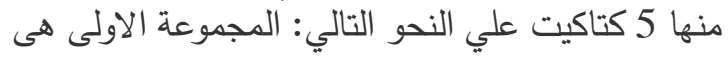
الضابطة (الكنترول) وكانت بدون إضافات؛ والئه المعاملتبن

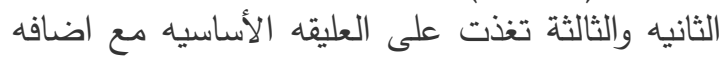
النحاس في الصورة غير عضوية (كبريتات النحاس) بمستويات 50-100 جزء في المليون بينما المعاملتين

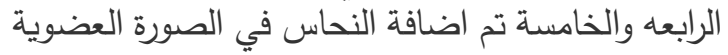

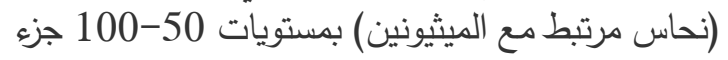

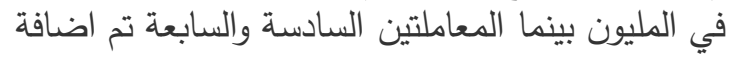
النحاس في صورة النانو بمستويات 50-100 جزي في في الفياني البليون. أظهرت النتائج حدوث زيادة معنوية في وزن فئن

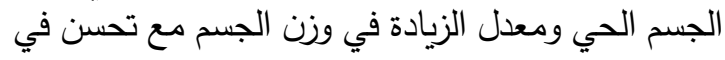

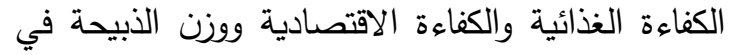

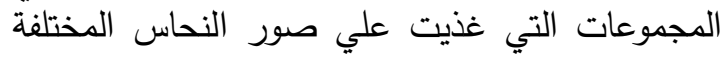

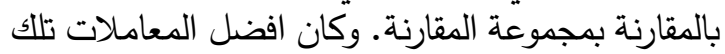

